\title{
KLK3 Gene
}

National Cancer Institute

\section{Source}

National Cancer Institute. KLK3 Gene. NCI Thesaurus. Code C26585.

This gene is involved in the hydrolysis of high molecular mass seminal vesicle protein, resulting in the liquefaction of seminal coagulum. 